\title{
The World Peace And the ISlamic Prospective
}

\author{
LA PAZ DEL MUNDO Y LA PERSPECTIVA ISLÁMICA
}

Bahram Navazeni*

Alireza Nabawi**

\begin{abstract}
World peace as an ideal situation associated with freedom and prosperity refers to a situation in which all the people of the world work together to avoid war and violence. This article is aimed at analyzing the formation and activation of the United Nations as a momentum of the international community. In Iran, after the Islamic Revolution of 1979 there has been an emphasis on dignity, human values and freedom, with responsibility before God. The Iranian constitution is opposed to all cruelty, oppression, domination and submission, and heralds the provision of social and political freedoms, within the limits of law. The present article is intended to use the descriptive-analytical method in order to study the positive concept of world peace. With the help of library resources and legal documents the present paper aims to explain the sustainable initiatives to creating of world peace contained in the Iranian Constitution, based on the Quranic verses and its interpretations of Ghotb in Egypt and Imam Khomeini in Iran. Among such principles of the constitution, is human happiness in Iran, in the entire Islamic Ummah, and in the whole human community. The Constitution also proclaims independence, freedom and the rule of justice and truth for all peoples.
\end{abstract}

Keywords: Global Peace, Freedom, Justice, Constitution, Islamic Republic of Iran

Resumen: La paz del mundo es una situación ideal asociada con la libertad y la prosperidad relacionada con una situación donde toda la humanidad trabaja junta para evitar la guerra y la violencia. Este artículo busca analizar la formación y las acciones de las Naciones Unidas como un momento de la comunidad internacional. En Irán, después de la Revolución islámica de 1979, se

\footnotetext{
* Department of Political Sciences, Imam Khomeini International University (Qazvin, Irán).info@ navazeni.ir

** Master student of International Relations, Kharazmi University (Tehran, Irán). alirezanabavi93@gmail.com
} 
ha puesto un énfasis en la dignidad, en los valores humanos y en la libertad, con responsabilidad ante Dios. La Constitución iraní se ha opuesto a toda crueldad, opresión, dominación o sujeción, y protege la libertades sociales y políticas, dentro de los límites de la ley. El presente artículo utiliza un método de análisis descriptivo, a fin de estudiar el concepto de paz mundial. Con la ayuda de las fuentes doctrinales y legales, los objetivos del estudio son explicar las iniciativas sostenibles para crear la paz mundial contenida en la Constitución iraní, basada en los versos del Corán y en las interpretaciones de Ghtb en Egipto y de Imam Khomeini en Irán. Entre estos principios de la Constitución está la felicidad humana en Irán, en toda la Ummah islámica y en toda la comunidad humana. La Constitución también proclama la independencia, la libertad, la norma de la justicia y la verdad para todas las personas.

Palabras clave: Paz global, libertad, justicia, constitución, República Islámica de Irán

Sumario. I. Introduction. II. World Peace and the Charter of the United Nations. III. Islamic Perspective. IV. Conclusion. References.

\section{INTRODUCTION}

World peace throughout history has been an ideal situation for mankind, associated with concepts such as freedom and prosperity by theologians, philosophers, jurists and politicians. Global peace refers to a situation in which all the people of the world work together to avoid war and violence. If a war breaks out in a region of the world, the aforementioned situation would presuppose that that all of mankind would put all their efforts into making peace where there is war.

The word "war" has different meanings in the Oxford Dictionary. The first is: «a situation in which two or more countries or groups of people fight against each other for a period of time». Other meanings are: «hostile competition between groups, companies or countries» and «fight or struggle for emancipation of anything unpleasant».

Concerning the fact that wars have destructive effects on individuals and societies, Hermidas Davood Bavand (2009, p. 82) maintains that since today no country is self-sufficient and independent from other societies, the imposition of economic sanctions can affect ordinary people sometimes as much as military wars. According to Saed (2014), there are two types of peace: positive peace and negative peace. Negative peace means lack of aggression, violence or war. In recent approaches to human security and human rights, this concept has become more extensive. Creating and 
maintaining legal relations among humans, states, and the security in social welfare are also included as integral parts of peace.

These two concepts of peace have always attracted the attention of the international community. The first concept of peace, the negative one, which means the avoidance and elimination of wars among countries is today considered excessively limited. Achieving this type of peace was the aim of the world peace movement in the $20^{\text {th }}$ century. Albert Einstein started the first wave of the world peace movement between the two World Wars with a group of determined activists against war: Bertrand Russell, Roman Rolland, Stefan Zweig and Carl Von Ossietzky. The movement tried to fight against the irresponsible leaders of many important countries, and mobilized the public opinion against aggression and the spread of weapons. In one of his speeches, Einstein said:

«Each war is a ring that adds to the chain of human misery and prevents human growth. (...) We must vaccinate our children against militarism and this only occurs when we teach them the spirit of peace. (...) Schoolbooks put a high value on wars and they simply ignore that wars result in fear and destruction, and in this way, they teach atrocity to our children» (Razaqhi, 2009, p. 94).

The second wave of the world peace movement started in late 1950s in the United Kingdom. The world peace movement stood against the Cold War, nuclear weapons and arms race. In 1961, hundreds of thousands of Germans held a mass rally with the motto "democracy and disarmament" and later they mobilized America's public opinion against Nixon's aggressive policies in Vietnam. The Soviet invasion of Czechoslovakia in the early 1970s caused a decline in the peace movement activities, but in the early 1980s, the third wave gained strength, and again millions of British and Germans held a rally against arms race (Razaqhi, 2009, pp. 94100).

The new and most widely accepted concept of world peace considers war as a sort of conflict that is not limited to use of force. This new concept includes the social relationships among the members of national and international communities (Saed, 2014).

This comprehensive and widely accepted approach, created by contemporary peace studies, has a considerable place in international normative. UNESCO, has accepted this approach since the early 1990s. UNESCO considers insecurity, social injustice, and economic inequality as important factors violating peace.

Despite the significant success made by people, states and the international community through the United Nations to avoid the outbreak of wars and arms race, world peace has not been completely achieved yet, 
so that many wars still break out in many corners of the world. One of these wars, the Iran-Iraq War, that lasted eight years, caused heavy material and spiritual losses not only for Iran, but in all the region and the world. The war between the international coalition and Iraq and Afghanistan also imposed heavy losses.

This article tries to use a descriptive-analysis method, and library resources to revise the intellectual framework for world peace and for the concept of "sustainable peace" maintained by liberalism. The article makes a comparison between the Holy Quran and the Islamic Republic of Iran's constitutional achievements. It also compares Ghotb's doctrine in Egypt with Imam Khomeini's interpretation of world peace, and the Islamic approach to sustainable peace.

\section{World Peace ANd The Charter of The United NATIONS}

Article 33 of the United Nations Charter refers to various means of resolving disputes before they lead to violent conflict. This article affirms that disputes, «the continuance of which is likely to endanger the maintenance of international peace and security» must be effectively resolved. It explains that the parties in such a conflict must, "first of all, seek a solution by negotiation, enquiry, mediation, conciliation, arbitration, judicial settlement, resort to regional agencies or arrangements, or other peaceful means of their own choice".

The Charter has also paid attention to some wider issues, such as the provision of conditions for creating and sustaining peace, including social and economic justice, human rights and respect for the rule of law. The preamble of the Charter reads:

«We the people of the United Nations determined to save succeeding generations from the scourge of war, which twice in our lifetime has brought untold sorrow to mankind, and to reaffirm faith in fundamental human rights, in the dignity and worth of the human person, in the equal rights of men and women and of nations large and small, and to establish conditions under which justice and respect for the obligations arising from treaties and other sources of international law can be maintained, and to promote social progress and better standards of life in larger freedom».

According to the normative attitude to peace of the Charter, the protection of «international peace and security» is the main objective of the United Nations, which has always worked to promote this value. 
September 21 was named as "the World Peace Day" in 1982, and is hence celebrated annually.

The more important document on peace in the United Nations is the Resolution A/RES/39/11 by the General Assembly of November 12, 1984, entitled "The right of peoples to peace" in which peace is recognized as a "human right". The resolution declares:

«1. Solemnly proclaims that the peoples of our planet have a sacred right to peace;

2. Solemnly declares that the preservation of the right of peoples to peace and the promotion of its implementation constitute a fundamental obligation of each state;

3. Emphasizes that ensuring the exercise of the right of peoples to peace demands that the policies of states be directed toward the elimination of the threat of war, particularly nuclear war, the renunciation of the use of force in international relations and settlement of international disputes by peaceful means on the basis of the Charter of the United Nations;

4. Appeals to all states and international organizations to do their utmost to assist in implementing the right of peoples to peace through adoption of appropriate measures at both national and international levels».

This normative attitude of the United Nations and its Charter can be attributed to the philosophical design of Immanuel Kant, who in 1795 in an article entitled "Sustainable Peace: A Philosophical Sketch" tried to define and present the authenticity of peace in the form of a discourse similar to the modern liberal democracy theory of "democratic peace". According to Kant's philosophical project, in order to achieve peace, governments must promptly take six important steps:

«1. No treaty of peace that tacitly reserves issues for a future war shall be held valid.

2. No independent nation, be it large or small, may be acquired by another nation by inheritance, exchange, purchase, or gift.

3. Standing armies shall be gradually abolished.

4. No national debt shall be contracted in connection with the foreign affairs of the nation.

5. No nation shall forcibly interfere with the constitution and government of another.

6. No nation at war with another shall permit such acts of war as shall make mutual trust impossible during some future time of peace: Such acts include the use of Assassins (percussores) Poisoners (venefici) breach of surrender, instigation of treason (perduello) in the opposing nation» (Kant, 2003, pp. 2-5).

According to Kant's advice, only subsiding of wars will not be enough to achieve the perpetual peace. For perpetual peace, the following principles expresses in these three steps must also be observed: 
«1. The civil constitution of every nation should be republican.

2. The law of nations should be founded on a federation of free nations.

3. The law of world citizenship should be limited to conditions of universal hospitality» (Kant, 2003, p. 8).

In fact, the idea of peacefulness in the United Nations Charter underlies the emergence of various laws and institutions in international relations that have originated from the concept of "democratic peace" or "liberal peace", based on the fundamental principles of individual freedoms and rights. The bases for liberalism, as Michael Doyle maintains, are bound to a set of three rights:

«1. Freedom from arbitrary power that is often called "negative liberty" and contain the freedom of opinion, freedom of the press and freedom of expression, equality before the law and the right to possess and exchange of property without fear of arbitrary capture.

2. Social and economic rights such as equality of educational opportunity and benefit from health care and work to maintain and strengthen the ability and opportunity to acquire the necessary freedom and "positive liberty" are important.

3. The right to participate or democratic representation to ensure that these two categories of rights are in a way that reflects the will of the citizens is the general rule of law affecting their communities» (Doyle, 2006, pp. 73-74 quoted from Beitz, 1979).

In these three categories of rights, citizens are considered morally autonomous and have the right of freedom. On the other hand, states, as representatives of their citizens, must have the rights of political independence and security from any foreign intervention. Thus, «mutual respect for these rights are understood as the standard Liberal International Theory» (Doyle, 2006, p. 82 quoted from Beitz, 1979). Doyle maintains that these three combined categories of rights may explain Kant's opinion about «organizing a group of rational beings requiring general rules for survival» and «in spite of the fact that their private attitudes are opposed (...) somehow neutralize each other (...) which [if] they did not have vicious attitudes» (Kant, 1795, p. 453).

However, as Doyle reconciles the three categories of liberal rights «liberalism's internal problem», the conflict between private property rights and equality of opportunity has led to organize free individuals in two different political systems «conservative liberalism and socialdemocratic liberalism» (Doyle, 2006, p. 74). These two systems collide with each other while claiming that in democratic peace, democratic states never fight each other, even if they have conflicts among themselves: such 
political structures rarely threat others to use force, since this is «illegitimate» (Lane, 2006, p. 246). However, this idea is based more on desire that in reality, and several cases of violation of this rule have been proved. There is no evidence to show that democracy at the unit level ceases the structure effects of anarchy at the international political system level (Lane, 2006, pp. 247-296).

Among other evidence is the atomic bomb being developed while the United Nations Charter in San Francisco conference was in progress, and the first atomic bomb detonation in Hiroshima on August $6^{\text {th }} 1945$, only 41 days after signing the United Nations Charter. Afterwards, for more than 45 years, the Cold War and the related nuclear threats, overshadowed the liberal order of the United Nations and its peacekeeping activities. Even with the collapse of the Soviet Union and the unprecedented increase of democratic structures in the world, this order still remains precarious.

Although historically and especially after the Second World War, some governments have practically ignored and rejected world peace. Moreover, public irresponsibility of many world leaders has caused deepening of the gap between south and north countries, which, according to Peck, undermines the effort of the international community, including the United Nations, to secure the connection between peace, security and development (Peck, 2002, p. 36). Peck, the founder of the "peace building program and preventive democracy" in the United Nations Institute for Training and Research in Geneva, Switzerland, and coordinator of the program, affirms that:

«If sustainable peace is required, it must be reinforced through a long-term approach till structural causes of conflict are considered and some institutes must be supported, to promote distributive justice which has been proven effective in reducing possibility of conflicts» (Peck, 2002, p. 39)

In her opinion, although complaints in the present day come from contemporary factors, most of them have historical roots of violence, related also to injustice enacted by colonialism, states and empires, the weakening of indigenous people, and mass emigration of people. According to her, in many cases, insufficient actions are done in order to compensate for the resulting imbalance, and today these imbalances are obvious in systematic patterns of discrimination and injustice. In order to prevent conflicts, she recommends that contemporary procedures should be reformed (Peck, 2002, p. 40).

Since states are responsible for their people in terms of physical and cultural security, and states legalize people's access to political and economic issues, in her view, the main goal of mobilizing groups is 
"political access". When states recognize dissatisfaction of dissident groups, listening to them and working with them may reduce or even eliminate people's complaints. However, when governments ignore or suppress these considerations, these problems may occur again (Peck, 2002, p. 41)

According to Peck, the concept of "human security" is the best foundation on which state security could be built and as the evidence shows, the safest states are those that provide more human security for their people while the weak states are those that do not. In her view, this weakness may lead countries' political elite to a vicious circle, resulting in undermining their own security and their people. In an effort to ensure their security, the ruling elite monopolizes all power tools through massive investments in weapons or using repressive strategies. Not using money to meet the needs of people, in the long term increases discontent among people and consequently will lead to greater vulnerability for elites. Therefore, she proposes that helping governments to increase their capacity to provide human security is an effective method preventing conflicts (Peck, 2002, p. 49)

According to Peck (2002, pp. 41-42), between development, human rights and peace, there must be a strong connection in order to solve the early complications before they turn into a serious problem. In her opinion, this approach ensures "good governance" allowing for people «to set their priorities, to provide and promote their civil, political, economic, social and cultural rights, and a pluralistic space where people can live together peacefully and have freedom to be developed in all fields» (Peck, 2002, p. 42). She maintains, however, that "good governance" will be effective only when this approach applies to all levels of society (local, national, regional and international). In addition, all levels will be required to support individual human rights, and it is also necessary to develop methods in order to support and balance the various demands of different groups (ibidem.).

As a result, it will be argued that one of the goals of prevention is to build "human security" through developing international architecture whose people are structures of "good governance". This means helping local and national governments in developing "good governance" and assisting the poor in transitional governments (ibidem.). According to Peck, as the environmental responsibility and development merged together in a new concept called "sustainable development", the combination of "good governance" with prevention of conflicts is the best way to achieve "sustainable peace" (ibidem.). Peck, who has psychological background and expertise, affirms that power-centered techniques for 
intervention as a common practice in non-participatory relations, is not the most effective method in most cases and may lead to a counter powercentered reaction; the other side reaction will resist against leveraging to defend his/her freedom and thus creates a hostile relationship reducing the probability of persuasion (Peck, 2002, p. 43). She suggests a more effective method for leveraging in participatory relations where sociability, mutual assistance and problem-solving on bilateral bases may create ethnic motives to change. According to her, «this process when promotes mutual agreed standards and norms will be more effective, establishing the bases of successful participatory relations» (ibidem.).

By asserting the promotion of agreed standards and norms of governance, Peck refers to the United Nations and its more than 70 human rights instruments such as the Universal Declaration of Human rights, International Convention on Civil and Political Rights, and International Convention on Economic, Social and Cultural Rights, and also their subsequent declaration that, in her view, have provided the best policy in details for "good governance" and explained how governments should provide "human security":

«In this convention and other declarations, the key demands of individuals and social groups are described as a "duty" of the government, the relation between human needs as "rights", prevention of conflict is clearly recognized by those who drafted these standards, and governments are required to ensure the human rights for the sake of their interest» (Peck, 2002, p. 44).

To Peck (2002, pp. 44-45), if we are to develop "human security" and "good governance", the establishment of public agreed norms will be the first step. The significant factor in realizing these norms is to provide "assistance" and "positive motives" designed to help governance structures at all levels so that they could move in this direction. By pointing out three usual methods of dispute resolution: power-centered, right-centered, and profit-centered or problem-solving, she believes that the first and second method cause a win-lose situation, while the third method aims to achieve a win-win result. The cost analysis in measuring the impacts and resource consumptions, in her view, has proven the power-centered method extremely costly, whereas the problem-solving method is less costly. She prefers the problem-solving method and maintains that the result from this method will be the most stable one when people's complaints are met by the governments. Thus, the risk of incoming problems causing conflicts will be least (Peck, 2002, p. 50).

Therefore, she concludes that in an effort to achieve the sustainable peace as patron of governance at all levels in a society, the rule of law must 
be established (right-centered approach) and the problem-solving method (profit-centered approach) must be adopted as a normal procedure replacing the power-centered approach (ibidem.).

\section{ISLAMIC PERSPECTIVE}

As mentioned before, the emphasis on the requirements of the world peace in the Islamic Republic of Iran's Constitution is quite relevant to the teachings of the Quran and Islam, including the Jihad concept. Jihad on legal and judicial terms is based on the Quran's injunctions. It means individual efforts to promote faith and belief in God, spreading belief in God, and exaltation of the word of God (Khaduri, 1956, p. 85) after full implementation of social and economic justice (Khosroshahi in Ghotb, 1976, p. 12). Therefore, based on Islamic theology, «war by itself is not the ultimate aim, but an instrument to provide and keep peace» (Khaduri, 1956, p. 214). The evidence of Islamic peaceful behavior is that in Prophet Mohammad's 80 battles in a 10-year period the number of human dead from both sides (Muslim and polytheists) did not exceed 1400. As Khosroshahi writes on Islam's objectives and plans at the time of the Prophet, before its progress, «Islam brought equality for different groups in the conquered lands by creating a new law and order and social and economic justice, and after the conquest, it had no effect on conquered lands except blessing, goodness, knowledge and virtue» (Khosroshahi in Ghotb, 1976, p. 16). Ghotb also believed that «Islam can bring more perfect and multilateral justice than any other justice system, cult or social school» (Ghotb, 1963, p. 30; Ghotb, 1973). To his view:

«Religion never solves human problems scatteredly and separately, it never meets them unrelated to other concepts and norms. However, methodologically, it is to diagnose all problems by reverting to a central point, with clear and sometimes tiny relations. All other elements are connected to a comprehensive axis and they circle around it, therefore issues and problems of religion constituted an overall unity. Based on what we have mentioned yet, in Islam, general way of thinking about world, life and human determines other lateral issues» (Ghotb, 1976, pp. 41-42).

Ghotb believed that the Ummah in Islam results from the point that God regards all humans as one solid Ummah (Ghotb, 1976, p. 45). This connection in nature of creation comes from the essence of human life, and these strengthen the concept of peace in Islam. Therefore, the concept of peace is the main principle and war is exceptional situation, which only occurs temporarily when the unity of Ummah is jeopardized (Ghotb, 1976, 
p. 49). Based on this, Islam refuses any war outbreaking due to racism, religious fanaticism, greed, material benefits, ambition and fame (Ghotb, 1976, pp. 49-51).

Ghotb maintained that the only legitimate war in Islam that Muslims are encouraged to serve in as the Prophet stated is a war to promote the word of God and waged to follow God's path. The meaning of "the word God" that is interpreted as "God's will" is clear for mankind, is compatible with unswerving tradition of creation and mankind (Ghotb, 1976, p. 51). One indication of reality of "the word of God" or "God's will" is that Islam brought this common good for all, and it removes any intervening factors between people and common good. By referring to the $39^{\text {th }}$ Quranic verse of Anfal «Fight them until there is no fitnah and worship is for Allah», Ghotb maintained:

«If someone intends to prevent people from the benefits of Public Good and does this by use of force, such a person is enemy of God and aggressor to "the word of God" and "God's will". We must get rid of him through peaceful methods then "the word of God" fulfills again. Therefore, we do not say that we can force them to accept Islam and follow Islam's rules. We must give them freedom of thought and extensive information that will lead them to God's path and prosperity» (Ghotb, 1976, p. 52).

Ghotb (ibidem.) believes that war in Islam must lead to disposal of intrigue, justice all over the world and bring real justice, including social justice, legislation justice and international justice in all human societies. Therefore, if someone wants to oppress others and deviates them from path of justice, even if he is Muslim, others are allowed to fight against him until he reverts to "the word of God" or "God's will". Afterward, those who stood against religion turn back to God's path. In his opinion, absolute justice and preventing injustice is a close concept to the word of God that must be always above all. The $9^{\text {th }}$ Quranic verse of Hojorat says:

«If two factions among the believers should fight, then make settlement between the two. But if one of them oppresses the other, then fight against the one that oppresses until it returns to the ordinance of Allah. And if it returns, then make settlement between them in justice and act justly. Indeed, Allah loves those who act justly».

Addition, the $190^{\text {th }}$ verse of Baghara «Fight in the way of Allah those who fight you but do not transgress. Indeed. Allah does not like transgressors» emphasizes on the importance of justice in Islam.

Some verses of the Quran used the term "ollov", that means that cruelty must be controlled as a human instinct. In the Quranic terminology, 
this word used in addition to words like rebellion and mutiny, being introduced as an anti-order reality (Makhluf, 2008, p. 147). The Quran speaks about Belqeis (verse $83^{\text {rd }}$ Ghesas) and Pharaoh (verse 4 of Ghesas), warns them about "ollov", which may lead to rebellion and disturbance of public security, even orders Muslims to prevent "ollov" and corruption on the Earth (verse $83^{\text {rd }}$ of Ghesas). Ghotb maintained that if verse 60 of Anfal encourages believers to "prepare against them whatever you are able of power and of steeds of war by which you may terrify the enemy of Allah" or in the verse $35^{\text {th }}$ of Mohammad warns believers that «do not weaken and call for peace while you are superior; and Allah is with you and will never deprive you of your deeds» are only in exceptional cases namely:

«1. Creation of prosperity and good for humanity (...) not just good for a nation, race, or individual,

2. The realization of excellent examples of human ethics as the ultimate goal of creation and life, loss,

3. Security for people, to save them from pressure, fear, oppression and

4. Establishing absolute justice throughout the land, that only under these circumstances "the word of God" is above all» (Ghotb, 1976, p. 56).

Describing the essence of peace in Islam, Ghotb used the concept of world peace that is also the subject of this article and believed that «to realize its ultimate aim, Islam initiates a long way, crosses through inner peace toward home peace and reconciliation, societal peace and ultimately world peace» (Ghotb, 1976, p. 60).

Based on the framework of this Islamic thought, Imam Khomeini maintains that peace is valuable only when human rights are reserved and justice is brought: without justice peace is meaningless.

«The world will never achieve security, peace and tranquility while it is captured by false peacemakers; peace lovers and advocates of human rights and human dreams will never come true, but humanity will achieve freedom and prosperity only when true believers and followers of divine ideologies work together» (Imam's Sahife, vol. 17, pp. 306-307).

In his opinion, establishing true peace in the world is a good thing that he hoped it taking over the world: «world peace is established based on national independence, non-interference in other countries' affairs and protection of territorial integrity of the countries in the region» (Imam's Sahife, vol. 12, p. 153). To him, existence of arrogant superpowers and surrendering to this situation by other countries prevented the realization of God's promise and "world peace depends on the extinction of the 
oppressors, while there are cultureless hegemons on the earth, the poor do not reach their inheritance God has forwarded them" (Imam's Sahife, vol. 12, p. 144).

Hassan Rouhani, the president of the Islamic Republic of Iran also believes that the world peace has a significant priority so far as in the $68^{\text {th }}$ meeting of the United Nations General Assembly, he suggested that the draft of "the world against violence and extremism" be on the United Nations agenda and the proposition of «coalition for sustainable peace» replaces the already "coalition for war" in different regions of the world (Rouhani, 2013). On the sidelines of this meeting with foreign ministers of nonaligned countries, he referred to the constituent aspirations of the NAM saying:

«The United Nations Charter is an appropriate guideline to members of the United Nations to establish just and sustainable peace throughout the world. The most important principle to which we have committed ourselves is the non-use of force or threat of force in international relations that is against United Nations Charter. Supporting all efforts made to promote principle of equality of all states, respect territorial integrity and political independence, the peaceful resolution of disputes based on the principle of justice and international law, are from other major principles that is emphasized by the United Nations Charter».

\section{CONCLUSION}

1. The concept of "world peace" as a human ideal, refers to not only avoidance of war and violence, but also cooperation on peaceful settlement of disputes, and calls for freedom, security, development and human prosperity around the world. This movement received momentum in the $20^{\text {th }}$ century by the international community and was used as a model for the formation and activation of international organizations, including the United Nations. In addition to its preserving international peace and security, as the most important task, the United Nations has paid a close attention to the relationship between peace, security and development, and has largely struggled to safeguard the distribution of justice around the world.

2. Likewise, the Islamic perspective on human dignity and happiness as elaborated by Ghotb in Egypt and Imam Khomeini in Iran after the Islamic Revolution of 1979, preserves a positive peace for all humanity around the world and the newest suggestion for "coalition for sustainable peace" by President Rouhani indicates this sustainable preservation. 


\section{REFERENCES}

Bavand, Hermidas D (2009). National and Public Interests of Iran in Realizing Peace, Human Rights and Sustainable Developments Troika. In Zhila Shariatpanahi and Isa Saharkhiz, Sustainable Peace: a long way and downs, (collection of articles). Tehran: Ghalam.

Beitz, Charles (1979). Political Theory and International Relations. Princeton: Princeton University Press.

Doyle, Mikel (2006). Kant, The Liberal Heritage and Foreign Affairs. In Andrea Linklater, The Liberal Peace (translated by Alireza Tayeb). Tehran: Ministry of Foreign Affairs.

Ghotb, Sayed (1963). Islam and the World Peace. Translated by Zeinolabedin Ghorbani and Sayed Hadi Khosrowshahi. Tehran: Enteshar.

Ghotb, Sayed (1973). Social Justice in Islam. Translated by Sayed Hadi Khosrowshahi and Mohamad Ali Gerami. Tehran: Enteshar.

Ghotb, Sayed (1976). The Infrastructure of the World Peace (translated by Sayed Hadi Khosrowshahi and Zeinolabedin Ghorbani). Tehran: Ramin.

Kant, Emmanuel (2001). The Sustainable Peace. Translated by Mohamad Sabouri. Tehran: BehBavaran.

Kant, Immanuel (1795). Perpetual Peace. In Carl J. Freiedrich, (ed.) (1949), The Philosophy of Kant. New York: Modern Library.

Kant, Immanuel (2003). To Perpetual Peace: a Philosophical Sketch. Translated by Ted Humphrey. Indianapolis: Hackett Publishing.

Lane, Kristopher (2006). Kant; the Myth of Democratic Peace. In Andrea Linklater, The Liberal Peace. translated by Alireza Tayeb. Tehran: Ministry of Foreign Affairs.

Makhlouf, Mohammad (2008). The Interpretation and Explanation of Quran's Words. Translated by Hoseinali Ansarirad. Mashad: Astane Ghods Razavi.

Peck, Connie (2002). Sustainable Peace: Role of United Nations Organization and Regional Organizations in Preventing War (translated by Soheila Naseri). Tehran: Ministry of Foreign Affairs.

Razaghi, Sohrab (2009). The Global Peace Movement: the Iranian Civil Society and the Winter Sleep. In Zhila Shariatpanahi and Isa Saharkhiz, Sustainable Peace: a long way and downs, (collection of articles). Tehran: Ghalam.

Rouhani, Hasan (2013). Speech in $68^{\text {th }}$ Session of the UN General Assembly. New York (retrieved at http://www.president.ir/fa/71572 on 11-IX-2017).

Saed, Nader (2014). The World Peace: from Theory to Practice (retrieved at http://www.farsnews.com/printable.php?nn=13930629001606 on 11-IX-2017). 